\title{
Analisis Faktor-faktor yang Mempengaruhi SERAMBI Tingkat Pertumbuhan Ekonomi di Indonesia
}

\author{
Yuniarti, Wiwin Wianti, Nandang Estri Nurgaheni \\ Universitas Bina Sarana Informatika
}

Received 15Jul 2020

Revised 25 Sep 2020

Accepted 26Jun 2020

Online first 26 Aug 2020

\section{Paper type}

Research paper

Purpose This study aims to determine the factors of economic growth in 34 provinces in Indonesia. The variables used include labor force participation rate, human development index, Poverty Level, unemployment rate, income inequality, and economic growth. Methods- Secondary data from the Central Bureau of Statistics were processed using multiple linear regression. Findings- The study show that only force participation rate and unemployment rate were proven to significantly affect economic growth, while human development index, poverty level, and income inequality were not statistically significant. Implications- This study can provide important information on the factors shaping economic growth as a basis for future decision making.

\begin{abstract}
Abstrak
Tujuan- Penelitian ini bertujuan untuk mengetahui faktor-faktor pertumbuhan ekonomi di 34 provinsi di Indonesia. Variabel yang digunakan antara lain tingkat partisipasi angkatan kerja, indeks pembangunan manusia, tingkat kemiskinan, tingkat pengangguran, ketimpangan pendapatan, dan pertumbuhan ekonomi. MetodeData sekunder dari Badan Pusat Statistik diolah dengan menggunakan regresi linier berganda. Temuan- Studi tersebut menunjukkan bahwa hanya tingkat partisipasi angkatan dan tingkat pengangguran yang terbukti secara signifikan mempengaruhi pertumbuhan ekonomi, sedangkan indeks pembangunan manusia, tingkat kemiskinan, dan ketimpangan pendapatan tidak signifikan secara statistik. Implikasi- Studi ini dapat memberikan informasi penting tentang faktor-faktor yang membentuk pertumbuhan ekonomi sebagai dasar pengambilan keputusan di masa depan
\end{abstract}

Pedoman Sitasi: Yuniarti, P., Wianti, W., \& Nurgaheni, N. (2020). Analisis Faktor-faktor yang Mempengaruhi Tingkat Pertumbuhan Ekonomi di Indonesia. SERAM BI: Jurnal Ekonomi Manajemen Dan Bisnis Islam, 2(3), 169 - 176

D OI: https:/ / doi.org/ 10.36407/ serambi.v2i3.207
Keywords: Economic growth, labor force participation rate, human development index, Poverty Level, unemployment rate, income inequality

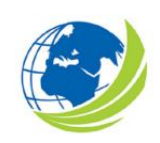

SERAMBI: Jurnal Ekonomi dan Bisnis Islam, Vol 2, No.3, 2020, pp. 169 - 176 elSSN 2685-9904 


\section{Pendahuluan}

Perekonomian suatu negara dikatakan mengalami perkembangan dan peningkatan pertumbuhan tingkat kegiatan ekonominya saat ini lebih tinggi dari apa yang telah dicapai pada saat sebelumnya. Pertumbuhan ekonomi nasional diketahui dari perubahan dari Produk Domestik Bruto (PDB) di tingkat nasional dari tahun ke tahun. Keberhasilan pembangunan suatu daerah atau negara, salah satunya dapat dilihat berdasarkan laju pertumbuhan ekonomi. Setiap daerah selalu menetapkan target laju pertumbuhan yang lebih baik dari tahun sebelumnya pada perencanaan dan tujuan pembangunan daerahnya.

Pada kenyataannya, manfaat pertumbuhan ekonomi suatu negara tidak otomatis dapat dinikmati oleh seluruh masyarakatnya. Terjadi ketimpangan dalam pendistribusian pendapatan, kemiskinan, dan pengangguran. Ketimpangan dari pendapatan bisa dilihat dari tingginya angka Indeks Gini Ratio. Akibat ketimpangan pendapatan, yang tinggi, kemiskinan juga terjadi lebih tinggi. Kemiskinan terus menjadi masalah fenomenal sepanjang sejarah Indonesia sebagai nation state, sebuah negara yang salah memandang dan mengurus kemiskinan. Dalam negara yang salah urus, tidak ada persoalan yang lebih besar selain persoalan kemiskinan. kemiskinan menyebabkan jutaan rakyat dalam memenuhi kebutuhan pangan, sandang dan papan secara terbatas (Hasyim, 2017). Kemiskinan menyebabkan masyarakat rela mengorbankan apa saja demi keselamatan hidup (safety life).

Menurut (Lidwina, 2020), tingkatketimpangan pengeluaran penduduk (rasio gini) meningkat. Pada Maret 2020, Badan Pusat Statistik (BPS) mencatat angka rasio gini sebesar 0,381. Angka tersebut naik 0,001 poin dibandingkan pada September 2019 sebesar 0,380. Kenaikan rasio gini terjadi di semua wilayah, baik perkotaan maupun perdesaan. Di perkotaan, rasio gini Maret sebesar 0,393 poin dari September 2019 sebesar 0,391. Sedangkan di perdesaan, sebesar 0,317 atau naik dari 0,315 pada September 2019. Sejalan dengan itu, Menteri Perencanaan Pembangunan Nasional (PPN)/Kepala Badan Perencanaan Pembangunan Nasional (Bappenas) Bambang Brodjonegoro mengemukakan, tingkat pertumbuhan ekonomi Indonesia hingga akhir tahun sulit melebihi 5,3 persen Untuk melihat apa penyebab lambatnya pertumbuhan tersebut kami melakukan yang namanya diagnosa pertumbuhan, dan ternyata faktor pertama dalam ekonomi Indonesia yang menghambat pertumbuhan adalah masalah regulasi dan institusi, Institusi,artinya birokrasi pemerintahan masih dianggap belum cukup handal untuk bisa memudahkan investasi maupun melancarkan di sektor perdagangan. Sedangkan di regulasi, hambatan utamanya adalah masih banyaknya regulasi. (Praditya, 2019).

Pertumbuhan ekonomi, ketimpangan pendapatan, dan kemiskinan adalah isu-isu yang selalu menarik untuk dipelajari. Berbagai studi sebelumnya mencoba untuk menjelaskan faktor yang dapat mempengaruhi pertumbuhan ekonomi (misal nya Masli, 2008; Putri, Amar, \& Aimon, 2015; Paksi, 2016; Nugroho, 2017; Hapsari \& Iskandar, 2018). Meskipun sudah banyak diteliti, hasil studi belum menemukan faktor atau determinan yang secara konsisten mempengaruhi pertumbuhan ekonomi. Sebagai contoh, studi Masli (2006) menemukan bahwa teknologi, peningkatan sumber daya manusia, penemuan material baru, peningkatan pendapatan dan perubahan selera konsumen merupakan faktor penting dalam meningkatkan pertumbuhan ekonomi.. Menggunakan Pendapatan Asli Daerah, Tenaga Kerja, Tingkat Pendidikan, dan Net Ekspor, studi Paksi (2016) menemukan bahwa Pendapatan Asli Daerah memiliki pengaruh yang negatif dan tidak signifikan terhadap pertumbuhan ekonomi. Sementara tenaga kerja, tingkat pendidikan, dan net ekspor memiliki pengaruh yang positif dan signifikan terhadap pertumbuhan ekonomi. Nugroho (2017) menemukan bahwa upah, dan jumlah penganguran signifikan mempengaruhi terhadap perumbuhan ekonomi. Hapsari et al. (2018) menemukan hal 
berbeda dimana peningkatan jumlah penduduk dan pendidikan akan meningkatkan pertumbuhan ekonomi secara signifikan. Peningkatan investasi swasta dari tahun ke tahun dapat menurunkan pertumbuhan ekonomi secara signifikan. Peningkatan belanja modal dan fasilitas kesehatan tidak berpengaruh signifikan terhadap pertumbuhan ekonomi.

Memperhatikan adanya perbedaan hasil maupun faktor yang digunakan untuk menjelaskan pertumbuhan ekonomi, studi ini bertujuan untuk mengevaluasi determinan pertumbuhan ekonomi secara lebih luas dengan menempatkan tingkat partisipasi angkatan kerja, indeks pembangunan manusia, tingkat kemiskinan, tingkat pengangguran, ketimpangan pendapatan. Hasil studi ini dapat memberikan perspektif yang lebih luas mengenai faktor penentu pertumbuhan ekonomi di 34 provinsi di Indonesia.

\section{Kajian Pustaka}

Teori Pertumbuhan Ekonomi

Simon Kuznet salah satu ekonom besar peraih hadiah nobel di bidang ekonomi pada tahun 1971 memberikan definisi bahwa pertumbuhan ekonomi adalah kenaikan kapasistas dalam jangka panjang dari negara yang bersangkutan untuk menyediakan berbagai barang ekonomi kepada penduduknya. Kenaikan kapasitas itu sendiri ditentukan atau dimungkinkan oleh adanya kemajuan atau penyesuaian-penyesuaian teknologi, institusional (kelembagaan), dan ideologis terhadap tuntutan-tuntutan yang ada (Saputra, 2016).

Menurut Dornbusch et.al. dalam (Hasyim, 2017), tingkat pertumbuhan perekonomian adalah kondisi dimana nilai riil produk domestik bruto (PDB) mengalami peningkatan (Dornbuschet al, 2008). Penyebab Utama dari pertumbuhan ekonomi adalah tersedianya sejumlah sumber daya dan peningkatan efisiensi penggunaan faktor produksi. Pertumbuhan ekonomi dalam pengertian ekonomi makro adalah penambahan nilai PDB riil, yang berarti peningkatan pendapatan nasional. Pertumbuhan ekonomi ada dua bentuk: ekstensif yaitu dengan penggunaan lebih banyak sumber daya atau intensif yaitu dengan penggunaan sejumlah sumber daya yang lebih efisien (lebih produktif). Ketika pertumbuhan ekonomi dicapai dengan menggunakan banyak tenaga kerja, hal tersebut tidak menghasilkan pertumbuhan pendapatan per kapita. Namun ketika pertumbuhan ekonomi dicapai melalui penggunaan sumberdaya yang lebih produktif, termasuk tenaga kerja, hal tersebut menghasilkan pendapatan per kapita yang lebih tinggi dan meningkatkan standar hidup rata- rata masyarakat.

Tingkat Partisipasi Tenaga Kerja

Tingkat Partisipasi Angkatan Kerja (TPAK) adalah Penduduk yang termasuk bukan angkatan kerja adalah penduduk usia kerja (15 tahun dan lebih) yang masih sekolah, mengurus rumah tangga atau melaksanakan kegiatan lainnya selain kegiatan pribadi (Data.go.id, 2018).

Indeks Pembangunan M anusia (IPM )

IPM (BPS, 2020a) menjelaskan bagaimana penduduk dapat mengakses hasil pembangunan dalam memperoleh pendapatan, kesehatan, pendidikan, dan sebagainya. IPM diperkenalkan oleh U nited $\mathrm{N}$ ations D evelopment Programme (UNDP) pada tahun 1990 dan dipublikasikan secara berkala dalam Iaporan tahunan Human Development Report (HDR). IPM dibentuk oleh 3 (tiga) dimensi dasar, yaitu (1) umur panjang dan hidup sehat, (2) pengetahuan, (3) standar hidup layak. IPM merupakan indikator penting untuk mengukur keberhasilan dalam upaya membangun kualitas hidup manusia (masyarakat/ penduduk) dan dapat menentukan peringkat atau level pembangunan suatu wilayah/ negara. 


\section{Tingkat Kemiskinan}

Untuk mengukur kemiskinan, (BPS, 2020b) menggunakan konsep kemampuan memenuhi kebutuhan dasar (basic needs approach). Dengan pendekatan ini, kemiskinan dipandang sebagai ketidakmampuan dari sisi ekonomi untuk memenuhi kebutuhan dasar makanan dan bukan makanan yang diukur dari sisi pengeluaran. Jadi penduduk miskin adalah penduduk yang memiliki rata-rata pengeluaran perkapita perbulan dibawah garis kemiskinan.

Tingkat Pengangguran

Tingkat Pengangguran (BPS, 2020c) adalah persentase jumlah pengangguran terhadap jumlah angkatan kerja. Tingkat pengangguran merupakan indikator yang biasa digunakan untuk menganalisis sehat atau tidaknya perekonomian suatu negara.

\section{Ketimpangan Pendapatan}

Ketimpangan pendapatan (Riadi, 2020) adalah suatu konsep yang menjelaskan perbedaan kemakmuran, standar hidup, serta pendapatan yang diterima atau dihasilkan oleh individu atau rumah tangga dalam masyarakat sehingga mengakibatkan tidak meratanya distribusi antar wilayah disebabkan oleh perbedaan faktor produksi dan sumber daya yang tersedia. Indeks Gini dapat menunjukkan ketidaksetaraan melalui alat analisis rasio seperti pendapatan per kapita dan produk domestik bruto. Selain itu, Indeks Gini dapat digunakan untuk mengukur tingkat ketidakmerataan distribusi pendapatan penduduk di berbagai sektor dan negara. Indeks Gini dapat menunjukkan perubahan distribusi pendapatan dalam suatu negara selama periode waktu tertentu, sehingga mampu menunjukkan peningkatan atau penurunan dari ketimpangan pendapatan di suatu negara tersebut.

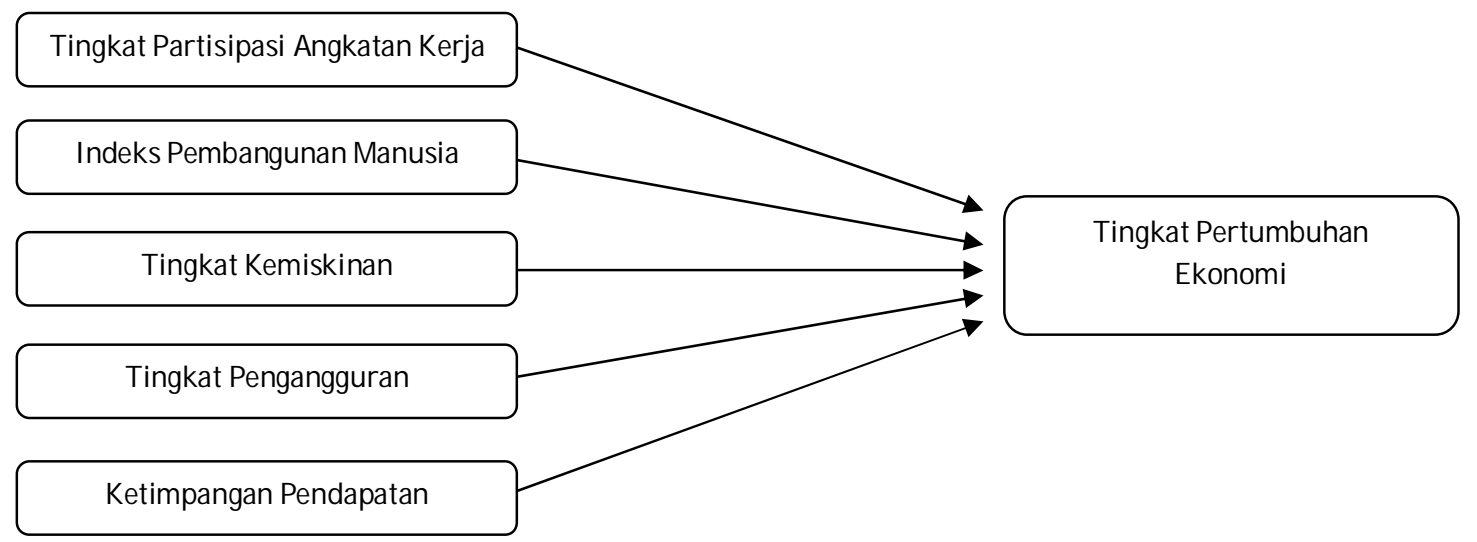

G ambar 1. Kerangka Teoritis

\section{Metode Penelitian}

Penelitian ini merupakan penelitian deskriptif, di mana yang digunakan untuk mencari unsurunsur, ciri-ciri, dan sifat-sifat suatu fenomena. Metode ini dimulai dengan mengumpulkan data, menganalisis data, dan menginterpretasikanya. Data yang digunakan dalam penelitian ini adalah data sekunder, berasal dari Badan Pusat Statistik yang telah dipublikasikan saat penulis akses pada Juli 2020. Teknik pengumpulan data dengan cara mengumpulkan data dan dokumendokumen yang sudah ada serta berhubungan dengan variabel penelitian seperti data yang 
berasal dari Badan Pusat Statistik. Data yang dipergunakan adalah:

1. Tingkat partisipasi angkatan kerja dari 34 provinsi di Indonesia, tahun 2018

2. Indeks pembangunan manusia dari 34 provinsi di Indonesia, tahun 2018

3. Tingkat kemiskinan dari 34 provinsi di Indonesia, tahun 2018

4. Tingkat pengangguran dari 34 provinsi di Indonesia, tahun 2018

5. Ketimpangan pendapatan dari 34 provinsi di Indonesia, tahun 2018

Alasan pemilihan tahun 2018 karena penulis mempertimbangkan ketersediaan data yang sudah dipublikasikan. Untuk mengetahui besarnya pengaruh dari beberapa faktor terhadap tingkat pertumbuhan ekonomi di Indonesia, tahun 2018. Penulis menggunakan SPSS 23 untuk melakukan analisis statistik regresi berganda atau multiple linear regression model of ordinary least square (OLS) pada tingkat signifikan $5 \%$

\section{Hasil dan Diskusi}

Untuk menganalisis dan menjelaskan pengaruh faktor-faktor atau variabel tingkat partisipasi angkatan kerja, indeks pembangunan manusia, tingkat kemiskinan, tingkat pengangguran, ketimpangan pendapatan, terhadap tingkat pertumbuhan ekonomi hasil pengolahan data dari kuesioner dianalisis menggunakan regresi linear berganda dengan model O rdinary Least Square (OLS)

Tabel 1. Koefisien

\begin{tabular}{llrr}
\hline Model & & \multicolumn{2}{c}{ Sig. } \\
\hline 1 & (Constant) & 1,253 &, 021 \\
\hline & Tingkat_Partisipasi_Angkatan_Kerja & 1,747 &, 042 \\
\hline Indeks_Pembangunan_Manusia &, 890 &, 081 \\
\hline Tingkat_Kemiskinan &, 791 &, 136 \\
\hline Tingkat_Pengangguran & 1,356 &, 046 \\
\hline Ketimpangan_Pendapatan &,- 176 &, 362 \\
\hline Dependent Variable: Tingkat_Pertumbuhan_Ekonomi & &
\end{tabular}

Berdasarkan hasil pengujian koefisien regresi secara individual dengan uji t menunjukkan bahwa variabel tingkat partisipasi angkatan kerja (X1) dan tingkat pengangguran (X4) dan secara signifikan mempengaruhi tingkat pertumbuhan ekonomi di Indonesia (Sig. $\leq 0,05)$. Sedangkan indeks pembangunan manusia (X2), tingkat kemiskinan (X3), dan ketimpangan pendapatan (X5) tidak signifikan mempengaruhi tingkat pertumbuhan ekonomi di Indonesia (Sig.>0,05)

Tabel 2. Koefisien Determinasi

\begin{tabular}{ccc}
\hline Model & $\mathrm{R}$ & $\mathrm{R}$ Square \\
\hline 1 & ,339a &, 115 \\
\hline
\end{tabular}

Berdasarkan hasil analisis koefisien determinasi pada tabel 2, diperoleh nilai $\mathrm{R}^{2}$ sebesar 0,115 . Hal ini berarti bahwa variabel-variabel independen (tingkat partisipasi angkatan kerja, indeks pembangunan manusia, tingkat kemiskinan, tingkat pengangguran, dan ketimpangan pendapatan) dalam model mampu menjelaskan variabel dependen (tingkat pertumbuhan ekonomi) sebesar $11,5 \%$ sedangkan sisanya $88,5 \%$ dijelaskan oleh variabel-variabel lain yang tidak dijelaskan dalam penelitian ini. 
Tabel 3. Koefisien Regresi

\begin{tabular}{|c|c|c|}
\hline \multirow[b]{2}{*}{ Model } & \multicolumn{2}{|c|}{ Unstandardized Coefficients } \\
\hline & B & Std. Error \\
\hline 1 (Constant) & 15,370 & 12,265 \\
\hline Tingkat_Partisipasi_Angkatan_Kerja & ,276 & 158 \\
\hline Indeks_Pembangunan_Manusia & 030 & 000 \\
\hline Tingkat_Kemiskinan & 002 & 002 \\
\hline Tingkat_Pengangguran & ,005 & 004 \\
\hline Ketimpangan_Pendapatan &,- 002 & 011 \\
\hline
\end{tabular}

Dependent Variable: Tingkat_Pertumbuhan_Ekonomi

Dari tabel 3, diperoleh persamaan regresi sebagai berikut: $Y=15,370+0,276 X_{1}+0,030 X_{2}+$ $0,002 X_{3}+0,005 X_{4}-0,002 X_{5}+$ e. Konstanta $(\alpha)=15,370$, menunjukkan jika nilai variabel-variabe independen (tingkat partisipasi angkatan kerja, indeks pembangunan manusia, tingkat kemiskinan, tingkat pengangguran, dan ketimpangan pendapatan $=0$, maka tingkat pertumbuhan ekonomi di Indonesia tahun 2018 sebesar $15,370 \%$.

Koefisien $X_{1}$ (tingkat partisipasi angkatan kerja)=0,276, menunjukkan bahwa setiap kenaikan tingkat partisipasi angkatan kerja sebesar $1 \%$, maka tingkat pertumbuhan ekonomi di Indonesia akan meningkat sebesar $0,276 \%$. Koefisien $\mathrm{X}_{2}$ (indeks pembangunan manusia) $=0,030$, menunjukkan bahwa menunjukkan bahwa setiap kenaikan indeks pembangunan manusia sebesar 1\%, maka tingkat pertumbuhan ekonomi di Indonesia akan meningkat sebesar 0,030\%. Koefisien $\mathrm{X}_{3}$ (tingkat kemiskinan) $=0,002$, menunjukkan bahwa menunjukkan bahwa setiap kenaikan tingkat kemiskinan sebesar $1 \%$, maka tingkat pertumbuhan ekonomi di Indonesia akan meningkat sebesar $0,002 \%$. Koefisien $\mathrm{X}_{4}$ (tingkat pengangguran) $=0,005$, menunjukkan bahwa menunjukkan bahwa setiap kenaikan tingkat pengangguran sebesar $1 \%$, maka tingkat pertumbuhan ekonomi di Indonesia akan meningkat sebesar 0,005\%. Koefisien $\mathrm{X}_{4}$ (ketimpangan pendapatan) $=0,002$, menunjukkan bahwa menunjukkan bahwa setiap kenaikan tingkat pendapatan sebesar 1\%, maka tingkat pertumbuhan ekonomi di Indonesia akan menurun sebesar $0,002 \%$.

\section{Pembahasan}

Studi ini hanya berhasil membuktikan tingkat partisipasi angkatan kerja dan tingkat pengangguran yang signifikan mempengaruhi pertumbuhan ekonomi daerah. Sedangkan indeks pembangunan manusia, tingkat kemiskinan, dan ketimpangan pendapatan tidak signifikan mempengaruhi tingkat pertumbuhan ekonomi di Indonesia. Hasil tidak sejalan dengan studi Masli (2006) menemukan bahwa peningkatan sumber daya manusia merupakan faktor penting dalam meningkatkan pertumbuhan ekonomi.. Paksi (2016) menemukan bahwa tenaga kerja dan tingkat pendidikan memiliki pengaruh yang positif dan signifikan terhadap pertumbuhan ekonomi. Hasil studi ini juga berbeda dengan Nugroho (2017) yang menemukan bahwa upah, dan jumlah penganguran signifikan mempengaruhi terhadap perumbuhan ekonomi, dan Hapsari et al. (2018) menemukan pendidikan akan meningkatkan pertumbuhan ekonomi secara signifikan.

Hasil yang berbeda kemungkinan dikarenakan minimnya periode pengamatan yang dilakukan sehingga efek jangka panjang tidak teridentifikasi. Sebagai contoh, indeks pembangunan manusia kemungkinan memiliki efek jangka terhadap pertumbuhan ekonomi, sehingga periode pengamatan yang lebih panjang diperlukan untuk menjelaskan hubungan tersebut. 


\section{Kesimpulan}

Berdasarkan analisis yang telah dilakukan, tingkat partisipasi angkatan kerja dan tingkat pengangguran secara signifikan dan positif mempengaruhi tingkat pertumbuhan ekonomi di Indonesia. Sedangkan indeks pembangunan manusia, tingkat kemiskinan, dan ketimpangan pendapatan tidak signifikan mempengaruhi tingkat pertumbuhan ekonomi di Indonesia. Hasil analisis koefisien determinasi tingkat partisipasi angkatan kerja, indeks pembangunan manusia, tingkat kemiskinan, tingkat pengangguran, dan ketimpangan pendapatan mampu menjelaskan tingkat pertumbuhan ekonomi sebesar $11,5 \%$ sedangkan sisanya $88,5 \%$ dijelaskan oleh variabelvariabel lain yang tidak dijelaskan dalam penelitian ini.

\section{Keterbasan dan Saran}

Pada penelitian ini penulis hanya meneliti lima faktor atau 5 variabel independen yaitu tingkat partisipasi angkatan kerja, indeks pembangunan manusia, tingkat kemiskinan, tingkat pengangguran, dan ketimpangan pendapatan terhadap variabel dependen (tingkat pertumbuhan ekonomi) di 34 provinsi yang ada di Indonesia, pada tahun 2018. Alasan pemilihan tahun 2018 karena penulis mempertimbangkan ketersediaan data terbaru yang sudah dipublikasikan. Berdasarkan kesimpulan yang sudah diuraikan di atas, penulis berharap bahwa peneliti selanjutnya yang ingin mempelajari faktor-faktor yang mempengaruhi tingkat pertumbuhan ekonomi, dapat meneliti atau menambahkan variabel-variabel independen yang lain. Dan juga meneliti dengan penambahan beberapa tahun sebelumnya dan pada tahun-tahun yang akan datang.

\section{Daftar Pustaka}

Badan Pusat Statistik. (2020). Ekonomi Indonesia 2019 Tumbuh 5,02 Persen. Jakarta. Retrieved from https:/ / www.bps.go.id/ pressrelease/ 2020/02/ 05/ 1755/ ekonomi-indonesia-2019-tumbuh-5-02persen.html \#: :text=Ekonomi Indonesia tahun 2019 tumbuh,Komponen Pengeluaran Konsumsi Lembaga Nonprofit

BPS. (2020a). Indeks Pembangunan Manusia. Jakarta. Retrieved from https:/ / www.bps.go.id/ subject/ 26/ indeks-pembangunan-manusia.html

BPS. (2020b). Kemiskinan dan Ketimpangan. Jakarta. Retrieved from https:/ / www.bps.go.id/ subject/ 23/ kemiskinan-dan-ketimpangan.html

BPS. (2020c). Tenaga Kerja. Jakarta. Retrieved from https:/ / www.bps.go.id/ subject/ 6/ tenagakerja.html

Data.go.id. (2018). Tingkat Partisipasi Angkatan Kerja (TPAK) Menurut Provinsi. Retrieved from https:/ / data.go.id/ dataset/ tingkat-partisipasi-angkatan-kerja-tpak-menurut-provinsi

Hapsari, A. P., \& Iskandar, D. D. (2018). A nalisis Faktor-Faktor Yang M empengaruhi Pertumbuhan Ekonomi Provinsi Jawa Tengah Periode 2010-2014 (Doctoral dissertation, Fakultas Ekonomika dan Bisnis).

Hasyim, H. (2017). Reksadana Syariah vs Reksadana Konvensional: Analisis Pertumbuhan dan Perkembangan Tahun 2010-2016. A I-I qtishad, II (13), 122-136.

Lidwina, A. (2020, July 15). Tingkat Ketimpangan Penduduk Indonesia Meningkat. Databoks. Retrieved from https:/ / databoks.katadata.co.id/ datapublish/ 2020/ 07/ 15/ tingkatketimpangan-penduduk-indonesia-meningkat

Masli, L. (2008). Analisis faktor-faktor yang mempengaruhi pertumbuhan ekonomi dan ketimpangan regional antar kabupaten/ kota di Provinsi Jawa Barat. Jakarta: ST IE ST AN IM .

Nugroho, R. E. (2017). A nalisis Faktor-Faktor yang Mempengaruhi Pertumbuhan Ekonomi di Propinsi Banten. JIEM S (J ournal of Industrial Engineering and M anagement Systems), 10(1).

Paksi, A. K. E. (2016). Analisis Faktor-Faktor yang Mempengaruhi Pertumbuhan Ekonomi Provinsi Lampung.

Praditya, I. I. (2019, July 8). Pertumbuhan Ekonomi Indonesia 2019 Mentok di 5,3 Persen. 
Liputan6.Com. Retrieved from https:/ / www.liputan6.com/ bisnis/ read/ 4007833/ pertumbuhanekonomi-indonesia-2019-mentok-di-53-persen

Riadi, M. (2020, A pril 16). Ketimpangan Pendapatan (Pengertian, Penyebab dan Pengukuran). Kajian Pustaka.Com. Retrieved from https:/ / www.kajianpustaka.com/ 2020/ 04/ ketimpanganpendapatan-pengertian-penyebab-dan-pengukuran.htm

Saputra, D. (2016). A nalisis Pertumbuhan Ekonomi dan Tingkat Ketimpangan antar Kabupaten/ Kota di Provinsi Jawa Barat. CR Journal, 2(1), 1-18.

\section{Profil Penulis}

Puji Yuniarti, S.E., M.M. Iahir di Tanjunguban, Bintan, Kepulauan Riau. Lulus dari Program Studi S1 Ekonomi Pembangunan dan S2 Magister Manajemen di Universitas Trisakti Jakarta. Saat ini aktif mengajar sebagai dosen di Fakultas Ekonomi dan Bisnis Universitas Bina Sarana Informatika Jakarta dari tahun 2008 sampai dengan sekarang. Dengan mata kuliah yang diajarkan antara lain Pengantar Ekspor Impor, Metode Penelitian, Bahasa Indonesia, dan Statistika. Lulus dalam uji kompetensi dan memiliki sertifikat kompetensi sebagai Asisten Pelaksana Ekspor yang diselenggarakan oleh Lembaga Sertifikasi Profesi Ekspor Impor Indonesia. Alamat email yang dapat dihubungi adalah puji.pyi@bsi.ac.id

Wiwin Wianti, S.E., M.M. Iahir di Lebak, Banten. Lulus dari Program Studi S1 Ekonomi Manajemen Keuangan di Universitas Budi Luhur jakarta dan S2 Magister Manajemen Universitas Pembangunan Nasional "Veteran" Jakarta. Saat ini aktif mengajar sebagai dosen di Fakultas Ekonomi dan Bisnis Universitas Bina Sarana Informatika Jakarta dari tahun 2009 sampai dengan sekarang. Dengan mata kuliah yang diajarkan antara lain Pengantar Manajemen, Manajemen Logistik, Manajemen Perkantoran, Manajemen Kearsipan, Administrasi Bisnis, Pengantar Ekonomi Makro, Pengetahuan Kesekretarisan, Etiket dan Pengembangan Diri, Alamat email yang dapat dihubungi adalah wiwim.win@bsi.ac.id

Nandang Estri Nugraheni, S.E., M.M. lahir di Temanggung, Jawa Tengah. Lulus dari Program Studi S1 Manajemen UPN Veteran Yogyakarta dan S2 Magister Manajemen UBSI Bandung. Saat ini aktif mengajar sebagai dosen di Fakultas Ekonomi dan Bisnis Universitas Bina Sarana Informatika Jakarta dari tahun 2009 sampai dengan sekarang. Dengan mata kuliah yang diajarkan antara lain Manajemen Sumber Daya Manusia, Manajemen Operasional, Manajemen Pemasaran, Komunikasi Bisnis, dan Entrepreneurship. A ktif sebagai anggota lembaga kepedulian cagar budaya. Alamat email yang dapat dihubungi adalah nandang.nsg@bsi.ac.id

\section{Accepted author version posted online: 30 Agustus 2020}

$$
\text { (ㄷ) (1) }
$$

(C)2020 The Author(s). This open access article is distributed under a Creative Commons Attribution (CC-BY) 4.0 license 